○楯谷智子、影山龍一郎

京都大学 ウイルス研究所

Notch シグナル伝達系は、昆虫から哺乳類に至るまでよく保存されており、細胞分化の方向性を決定する重要なシグナル 系である。Notch シグナル伝達系においては、Notch 受容体にリガンドが結合すると、細胞表面の Notch 蛋白は特定のプロ テアーゼによる切断を受け、膜から遊離した細胞内ドメインがセカンドメッセンジャーを介することなくシグナルを核内へ と伝え、標的遺伝子の転写を活性化する。そのため、Notch 細胞内ドメインを過剩発現することにより、Notch シグナルを 活性化することが可能である。Notch シグナルは発生期の螖牛感覚上皮でも重要な役割を担っていることが報告されてお り、特に側方抑制による有毛細胞と支持細胞の運命決定がはよく知られている。しかしながら、蝸牛感覚上皮発生に扔ける Notch シグナルの活性化による影響については十分には調べられていないと思われる。そこで、Notch1 細胞内ドメインを コンディショナルに過剩発現させ Notch シグナル伝達系を持続的に活性化させるトランスジェニックマウスを作成した。 その解析結果につき報告する。

\title{
226 強大音曝露による内有毛細胞シナプス数の経時的変化
}

○金川英寿、菅原一真、豊田秀樹、御厨剛史、下郡博明、山下裕司

山口大学 大学院 医学系研究科 耳鼻咽喉科学分野

一過性域值上昇（TTS）では、強大音曝露後に内有毛細胞直下のシナプスや螖牛神経瀻維が、一旦障害されるが、徐々に 回復することが知られている。当科では、モルモットに強大音曝露（110dB、3 時間）を行い、TTS モデル動物を作成、サ ブスタンス $\mathrm{P}$ の内耳直接投与が $\mathrm{ABR}$ 闇值の回復を促進することを明らかにし、昨年の本学会で報告した。その中で強大音 曝露の 24 時間後に内有毛細胞直下のシナプス数が一時的に増加することを認めた。今回は、音響曝露後の有毛細胞直下のシ ナプス数を経時的に観察したので、報告する。過去の報告と同様、ハートレイ系モルモットを用い、同じ条件で強大音曝露 を行った。強大音曝露後、3、12、24時間、3、7 日後に断頭、抗 CtBP2 抗体を用いた免疫組織化学を行い、内有毛細胞 直下のシナプス数を計測した。過去の報告では、音響外傷 24 時間後にシナプス数が減少することが報告されているが、われ われの結果では、一時的にシナプス数が増加する傾向を認めた。この結果に、若干の文献的考察を加え、報告する。

\section{7 副鼻腔疾患に対するナビゲーション・システムの使用状況}

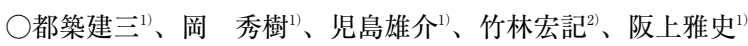

兵庫医科大学 医学部 耳鼻咽㑨科 ${ }^{1)}$ 、大阪厚生年金病院 ${ }^{2}$

【目的】眼窩、鼻涙管、頭蓋底などと隣接する副鼻腔疾患に対する手術では、ナビゲーション・システム（以下、ナビゲ ーション）の使用により安全な手術が可能となる。今回われわれは、当科におけるナビゲーション下に行った副鼻腔疾患の 手術症例について検討した。【対象】当科では2004年 9 月からナビゲーション（コールブリENT、ブレインラボ社、独）を 導入している。2011年11月までの 7 年 3 カ月間に、ナビゲーション下に行った副鼻腔手術症例は44例あった。男性 28 例、女 性16例。平均年齢53歳（16～80歳）。全身麻酔45例、局所麻酔 1 例。【結果】疾患の内訳は、副鼻腔囊胞 18 例 $(41 \%)$ が最多 で、副鼻腔炎14例（32\%）、副鼻腔腫瘍12例（27\%）であった。初回手術例（21例）よりも、鼻手術の既往がある例（23例） が多かった。ナビゲーションの標的とした副鼻腔病変は、前頭洞18例 $(41 \%) 、$ 前篩骨洞 15 例 $(34 \%)$ 、蝶形骨洞 5 例 (11\%)、後篩骨洞 3 例 $(7 \%)$ 、上䫈洞 3 例（7％）であった。【考察】ナビゲーションは、鼻術後症例や前頭洞疾患に使用 される頻度が高かった。

\section{8 手術支援機材としての DICOM ビューワ OsiriX（オザイリクス）の使用経験 〜鼻内視鏡手術を中心に〜 \\ ○二井一則 \\ 国立病院機構 弘前病院 耳鼻咽喉科}

近年の画像診断におけるデジタル化・フィルムレス化の推進によって CT P MRI、PET-CT などの画像は院内ネットワー ク端末で閲覧され、病院間の画像情報交換もネットワークや光学メディアを用いて行われるようになってきている。通常 CT よ゙のモダリテイから得られるデータは DICOM と呼ばれる国際標準化されたもので出力され、閲覧には専用のソフト ウエアが必要になる。さらに3D 再構築や画像内に関心領域（ROI）を書き込むといった操作のためには高価な機器や専用 ソフトウエア、専門知識を有した技術者や放射線科医の協力が必要であった。

現在ネット上で無償提供されている DICOM ビューワOsiriX は単なるビューワとしてだけではなく $3 \mathrm{D}$ 再構築や CT と MRI の重畳画像作成などが容易に行え、術前の患者説明やシミュレーション等様々な応用が可能となっている。さらに夕 ブレット端末にデータ転送する機能を備え、手術中の術者による画像閲覧操作が可能となっている。今回は鼻内視鏡手術を 中心に術前術中の OsiriX の有用性を検討したので報告する。 
○友田幸 ${ }^{11}$ 、村田英之 ${ }^{1)}$ 、馬場一泰1)、朝子幹也 ${ }^{11} 、$ 山下樹里 ${ }^{2}$

関西医科大学 耳鼻咽喉科 ${ }^{1)}$ 、産業技術総合研究所 ヒューマンライフテクノロジー2

手術手技の手順は、まず解剖を確認した上で安全な部位から切開、鉗除などの操作が始まるが、患者個人によって局所解 剖が異なること、術者自身が描くイメージも異なるため、手術初期にその操作方向、範囲を誤ると、術中に迷いが生じ危険 部位に侵入してしまう可能性がある。われわれはこれまで鼻副鼻腔のどの部位が誤認を生じ易いかをナビゲーションシステ 厶を用いて検証し、手術開始時に正しいオリエンテーションを付けることがその後の手術の成否と安全を左右することを報 告してきた。今回、レジデントレベルの医師と熟練医師を対象に、ヒト精密副鼻腔モデル（サージトレーナ社）を用いて、 誤認を生じ易い部位や危険部位、また重要な指標となる部位を ナビゲーション上であらかじめプロットしておき、どのよ うな操作やアプローチが誤解を招きやすいのかを検証し、その誤差計測を両者間で行いながら自分の手術を評価する方法を 考案した。この学習方法を基に理想的なアプローチ、手術部位の安全で確実な展開方法を自ら学ぶことができればと考えて いる。

\section{0 関西医科大学クリニカル・シミュレーションラボにおける鼻内内視鏡手術教育の試み}

○馬場一泰、村田英之、朝子幹也、友田幸一

関西医科大学 耳鼻咽喉科

鼻内内視鏡手術の初期段階の教育として、鼻・副鼻腔の手術解剖学的知識が必要であることは言うまでもないが、実際の 手術の際には内視鏡という限られた視野からの情報にCT 等の画像情報を組み合わせて立体的に全体像を把握する必要があ る。さらに、内視鏡の操作・銈子操作・内視鏡と銈子との干渉の回避等には若干の慣れが必要であり、不慣れな操作によ り、思わ䀦損傷が起こる可能性があり、それらの基本操作に関しては実際の手術で経験を積む以前にシミュレーションを 行う必要があると考える。現在、関西医科大学のクリニカル・シミュレーションラボに拈いてナビゲーションシステムおよ び精密ヒト鼻腔モデルを用いた鼻内内視鏡手術教育システムを構築したので報告する。

\section{1 副鼻腔モデルを使用した内視鏡下鼻内手術教育の $2 、 3$ の工夫}

○村田英之 ${ }^{1)}$ 、山下樹里 ${ }^{2)}$ 、馬場一泰 ${ }^{1)}$ 、朝子幹也 ${ }^{1)}$ 、友田幸 ${ }^{11}$

関西医科大学 耳鼻咽喉科 ${ }^{1)}$ 、(独) 産業技術総合研究所 ${ }^{2}$

内視鏡下鼻内手術（以下 ESS）教育は、教科書での自主学習、解剖実習コース参加、実際の手術（On The Scene）での マンッーマン指導に大きく分けられる。ただ、この一連の教育の中で内視鏡や鉗子操作などの基本技術を集中的に学ぶ部分 が少なく、研修者によってはラーニングカーブの上昇がなかなか得られにくい場合も経験する。また、On The Scene では 指導者の考え方が研修者に伝わりにくい場面も時に経験する。この背景を元にわれわれは副鼻腔モデルを ESS 教育に組み 込むことで、研修者が効率良く学べる環境作りを目指している。使用したモデルは(有)サージトレーナーの「精密ヒト鼻腔モ デル」である。このモデルを 1）副鼻腔解剖の理解、2）内視鏡、鉗子操作など基本技術の反復訓練、3） On The Scene で の同時デモンストレーションで使用して検討した。以上われわれが行っている ESS 教育の工夫を供覧する。

\section{2 p16 陽性中咽頭癌における導入化学療法の奏効率の検討}

○栗原理紗、篠原尚吾、菊地正弘、藤原敬三、山崎博司、岸本逸平、原田博之、内藤 泰 神戸市立医療センター中央市民病院 耳鼻咽喉科・頭頸部外科

【はじめに】ヒトパピローマウイルス（HPV）関連の中咽頭癌は予後良好であるとされ、今後 HPV 感染の有無に基づい て治療が選択されることが予想される。今回、p16 発現陽性中咽頭癌の発生率、臨床的特徵と、導入化学療法の奏効率を検 討した。【対象】2004年 4 月から2011年11月までに当院で生検し治療を行った新鮮例47例。男性37例、女性10例。年齢は 39 79歳 (中央值66歳)、観察期間中央值は945日であった。【方法】組織標本を免疫組織化学検查を用いて p16 発現を検討 し、腫瘍細胞内の陽性細胞率が50\%以上を陽性と定義した。p16 陽性例の臨床的特徵および、導入化学療法を行った 26 例に 関して、p16 発現と導入化学療法の奏効率に関連があるかを評価した。【結果】p16 陽性中咽頭癌は25例（53\%）であり、 有意に側壁型に多く、N分類に抢いて N2 症例が多かった。また、統計学的有意差はないが、p16 陽性例で生存率が高く、 非契煙者に多い傾向があった。一方、導入化学療法施行例（p16 陽性14例、陰性12例）において陽性例で奏効率が高い傾向 にあったが、統計学的有意差は認めなかった。 